\title{
Covid-19: UK government's defence of senior aide has damaged public and NHS confidence, say experts
}

\author{
Elisabeth Mahase
}

The BMJ

The UK government's handling of one of its most senior advisers who had seemed to break covid-19 lockdown rules has undermined the public health messaging and "trashed" behavioural advice on how to build trust and secure adherence to the measures needed to control the virus, experts have said.

The prime minister's senior aide Dominic Cummings admitted to driving $420 \mathrm{~km}$ with his wife, who had suspected covid-19, and their child from his home in London to his parents' estate in Durham. Cummings, who has said he does not regret his actions, travelled despite the government guidance telling people showing symptoms to stay at home and isolate.

In a press conference on 25 May to discuss the upset caused by his actions, which were revealed by the Guardian and Mirror, ${ }^{1}$ Cummings said that he made the journey as he thought that he might need childcare if he were to become seriously ill. However, he did not check whether he could get childcare assistance in London, and while in Durham he also drove 50 $\mathrm{km}$ from where he was staying to Barnard Castle to check whether his eyesight was good enough to drive back to London. Boris Johnson has defended Cummings, saying that he "followed the instincts of every father and every parent" and that he acted "responsibly, legally, and with integrity." However, at least 20 Conservative MPs have called for the adviser to be fired, and the minister for Scotland, Douglas Ross, has resigned in protest. $^{2}$ Some experts have said that, in defending Cummings, Johnson has undermined the government's public health messages and the rules that he has asked the public to follow for months.

Stephen Reicher, a member of the government's Scientific Pandemic Influenza Group on Behaviours and professor at the University of St Andrews, said, "As one of those involved in the government advisory group, I can say that in a few short minutes tonight Boris Johnson has trashed all the advice we have been given on how to build trust and secure adherence to the measures necessary to control covid-19.

"Be open and honest, we said. Trashed. Respect the public, we said. Trashed. Ensure equity, so everyone is treated the same, we said. Trashed. Be consistent, we said. Trashed. Make clear 'we are all in it together.' Trashed."

In an official statement the Faculty of Public Health said, "We are deeply concerned that recent actions from the government appear to undermine essential public health messaging at this crucial time. It is vital that all in society continue to follow guidance to prevent the spread of covid-19 and save lives. If there is doubt regarding the actions of those involved with the
Government, FPH supports, at the very least, an inquiry into the matter."

The NHS Confederation's chief executive, Niall Dickson, said, "We and our members are concerned at the damage that may be done to public and NHS staff confidence in government guidance because of the way this story has unfolded."

Around 300 GPs from the group GP Survival have also written to the chief constable of Durham police formally requesting an investigation into Cummings's claim that he drove $95 \mathrm{~km}$ with his wife and child to test his eyesight. ${ }^{4}$

However, while some medical leaders have voiced their concerns, others have remained publicly silent.

While appearing alongside the prime minister during the daily briefing on 24 May when journalists asked about Cummings's actions, NHS England's national medical director, Stephen Powis, did not raise any concerns and did not comment at all on the situation. ${ }^{5}$

The BMA has also said it did not want to get involved. A spokesperson told The BMJ, "The BMA, as a professional association, isn't going to be drawn into the debate about Dominic Cummings. The focus for the BMA during this pandemic is, and always has been, the safety of healthcare workers and the wider public and, now, how the pandemic is being brought under control."

GP Survival's chair, Nicolas Grundy, told The BMJ, "I suppose on one hand it's difficult for them [medical leaders] to hold the government to account in that their role is to advise . . . I suspect the argument they would use for avoiding outright criticism is the same one the Royal College [of General Practitioners] or the BMA would use-they need 'soft power,' they need to be 'in the room to influence decisions,' and so on. It is difficult to see evidence that their influence has appreciably improved the fallout from Cummings's actions."

https://www.mirror.co.uk/news/politics/dominic-cummings-investigated-police-after22072579.

https://twitter.com/Douglas4Moray/status/1265196839231533057/photo/1.

https://twitter.com/FPH/status/1264912683863814145

4 Philpotts E. Over 300 GPs urge police to investigate Dominic Cummings. 26 May 2020, Pulse. http://www.pulsetoday.co.uk/news/over-300-gps-urge-police-to-investigate-dominiccummings/20040865.article

5 Boris Johnson backs key aide Dominic Cummings in lockdown row-coronavirus covid-19 Update. YouTube. https://www.youtube.com/watch?v=tlc1rWg73MU

This article is made freely available for use in accordance with BMJ's website terms and conditions for the duration of the covid-19 pandemic or until otherwise determined by BMJ. You may use, download and print the article for any lawful, non-commercial purpose (including text and data mining) provided that all copyright notices and trade marks are retained. 
https://bmj.com/coronavirus/usage 